\title{
VESTIDOS PARA DESPUÉS DE UNA GUERRA. \\ La mujer y la moda en el Archivo Histórico NO-DO durante el periodo autárquico
}

\author{
Ana MELENDO CRUZ \\ Universidad de Córdoba \\ aa1mecra@uco.es
}

\begin{abstract}
DRESSES AFTER A WAR: Women and fashion in the NO-DO's Historical Archive
\end{abstract} during the autarchic period

Resumen: La aproximación a la obra documental del Archivo Histórico NO-DO, instrumento de propaganda de la dictadura, fiel a los presupuestos del régimen franquista, resulta decisiva a la hora de comprender la historia del documental en España en una de las épocas más convulsas de nuestro país: la autarquía. La investigación acerca de la moda femenina de estos años se convierte en nuestro principal objetivo, pues nos permite detectar las marcas de un tejido ideológico con el que componer la memoria de la colectividad y profundizar en conceptos referidos a la mujer como: servilismo, abnegación o sumisión.

Abstract: The Approximation to the documentary work from the NO-DO Historical Archives, propaganda tool for the Dictatorship true to the Franco regime's principles, is decisive when it comes to understand the history of the documentary in Spain during one of the most tumultuous periods of our country: the autarchy. The investigation regarding the women's fashion in said period becomes our the main objective as it allows us to detect the marks of an ideological fabric with which to compose the memory of the community and to deepen in concepts referred to the woman as: servility, abnegation or submission.

Palabras clave: NO-DO. Mujer. Revista Imágenes. Moda femenina. Autarquía

Women. Revista Imágenes. Women’s Fashion. Autarchy 


\begin{abstract}
"El vestido es el mejor ejemplo de cuanto la civilización inventó en beneficio de nuestro pudor, de nuestra moral y en ocultación de nuestra pobre anatomía o animalidad desnuda, no siempre agradable al público ni preservada por ella misma para guarecerse del frío o del calor después del pecado de nuestros primeros padres “(Sección Femenina, Enciclopedia elemental, 1957). ${ }^{1}$
\end{abstract}

\title{
Introducción
}

Cualquier producción cinematográfica puede definirse como un producto cultural y artístico que, siendo una manifestación de la sociedad que la produce, se convierte en un reflejo de la comunidad en la que se inscribe. Aunque es cierto que la mirada cinematográfica no es capaz de constituirse, en ningún caso, en relato objetivo de los acontecimientos históricos, también es verdad que los mensajes proyectados a través del cine son ecos de las sociedades en las que se desarrollan y, lo que es más importante, ayudan a componer la memoria de la colectividad. Y es que, como asegura Cristóbal Gómez Benito, "la historia visual" busca aportar la reflexión al conocimiento y a la difusión de los vínculos entre imágenes e historia, y en especial, al modo en que la imagen cinematográfica se erige en escritura complementaria de la que desarrollan las diversas corrientes historiográficas" (2015: 210). Pero, esa recuperación de la memoria histórica, que ha despertado en nuestro país un gran interés desde hace algún tiempo, exige, por lo general, de la revisión y el estudio de un patrimonio cultural que, como en el caso del Archivo Histórico NO-DO, se convierte en una fuente inagotable de información sobre uno de los periodos más convulsos, a la vez que apasionantes, de la historia de España. Resulta significativo al respecto que, en los últimos años, la observación del pasado haya absorbido a estudiosos de múltiples disciplinas, y todo ello porque, tal y como se señala en el "Plan de Estrategia Española de Ciencia y Tecnología y de Innovación 2016-2020", la historia y los recursos, las culturas locales y el patrimonio poseen un valor esencial en la construcción de las identidades y los valores comunes ${ }^{2}$. La importancia, entonces, de textos cinematográficos como el NO-DO, u otros similares, radica en su valor como documento histórico capaz de atestiguar los hechos del pasado, pero también en la forma fílmica contenida en ellos, dos aspectos a los que queremos referirnos en este trabajo partiendo de la imagen que se proyecta desde este Organismo gubernamental sobre la mujer y su vinculación con la moda.

Desde este planteamiento de partida, debemos empezar por reconocer que, en esa reconstrucción de lo ocurrido a través de la imagen cinematográfica, que nunca resulta fácil por los discursos dispares que de ella se desprenden, es posible leer las marcas de un ayer que nos permiten conocer e identificar las diferencias, sobre todo teniendo en cuenta que, como dice Rafael Tranche, "la historia de NO-DO se sitúa en paralelo y como reflejo mimético del propio Régimen [franquista]" (2006: 15). Es evidente que nuestro trabajo no quiere ocuparse de narrativas que desde el presente evocan el pasado, sino de otras que nacen en el pasado y que van a ser revisadas desde el presente. Se trata, por tanto, de la interpretación temporal de unos valores que forman parte de la vida de una sociedad, pero siempre teniendo en cuenta que, como asegura Eco, un texto, tal como aparece en su superficie (o manifes-

1 Recogido en: Otero (2004: 157).

2 Plan de Estrategia Española de Ciencia y Tecnología y de Innovación 2016-2020. Obtenido de: http://www.idi. mineco.gob.es/stfls/MICINN/Investigacion/FICHEROS/Estrategia_espanola_ciencia_tecnologia_Innovacion. pdf [Consulta: 23 de enero de 2017]. 
tación) lingüística, "representa una cadena de artificios expresivos que el destinatario debe actualizar" (1987: 73). Parece inevitable entonces que, en esa revisión, el destinatario del que habla Eco, se enfrente a los textos del pasado con sus propias normas y valores ${ }^{3}$ para convertirse así, como señala Iser, en "un potencial de efectos, que solo es posible actualizar en el proceso de lectura [...] Pues la obra es más que el texto, puesto que solo cobra su vida en la concreción y, por su parte, esta no se halla totalmente libre de las aptitudes que introduce el lector, aun cuando tales aptitudes sean activadas según los condicionantes del texto" (1987: 11-44).

Por otra parte, dice Gómez Benito, "La historia se ha basado en la primacía de lo escrito. Y tiene que afrontar el hecho de la utilización de ese testimonio de lo "visto" que es la imagen. En las manos del historiador, la imagen fotográfica [o cinematográfica en este caso] puede tener varios usos. Los dos principales tienen que ver con dos usos fundamentales de la historia: el registro de lo que ha sucedido y la narración de lo sucedido" (2015: 312). Pues bien, es precisamente en ese narrar lo sucedido donde entra en juego la forma de hacer de un Noticiario que, según Joaquín Soriano, director de la revista Primer Plano, "debe reflejar todos los aspectos nobles de la vida de nuestra nación: política, económica, artística, cultural, científica, deportiva, etc. También estos mismos aspectos, a ser posible, del mundo entero. Debe, en una palabra, informar, instruir y crear" (1942: 7). Ciertamente, "NO-DO surge como un mecanismo para controlar y centralizar la información audiovisual, del mismo modo que ya lo habían hecho otros regímenes totalitarios" (Tranche, 2006: 179). Sin embargo, el papel que se le otorga no es el mismo que el Régimen atribuía a la prensa escrita o a la radio porque, desde sus inicios, NO-DO se comporta como una revista en la que se elude la información a la actualidad, de tal forma que, gran parte de las noticias que aparecen son, en apariencia, irrelevantes para la historia ${ }^{4}$. Pero solo en apariencia, porque más allá de los objetivos marcados, en estos textos cinematográficos sobresalen las marcas de un tejido ideológico que señalizarán el camino que recorreremos hasta profundizar en aquellos aspectos relacionados con la mujer y la moda para, desde este punto de partida, explicar el papel que el género femenino desempeña en la sociedad franquista.

El análisis de algunos noticiarios y, sobre todo, de los documentales que en la Revista Imágenes aparecen sobre la moda femenina se convierte en fundamental para alcanzar nuestra finalidad. En este sentido partimos de la idea apuntada por Jacques Aumont y Michel Marie al considerar cualquier film como "una obra artística autónoma, susceptible de engendrar un texto (análisis textual) que ancla sus significaciones sobre estructuras narrativas (análisis narratológico), sobre aspectos visuales y sonoros (análisis icónico) y produce un efecto particular sobre el espectador (análisis psicoanalítico). Esta obra debe ser igualmente observada en el seno de la historia de las formas, los estilos y su evolución" (Aumont/Marie, 1988:8). Por tanto, partimos de la idea de que los documentales objeto de estudio se presentan como espacios textuales complejos capaces de suministrar una serie de datos que van más allá del contexto histórico o de la intencionalidad de sus realizadores. El estudio de los textos señalados conlleva, además, desentrañar, sin olvidarnos de los datos históricos que pudieran proporcionar, aquellos recursos cinematográficos que brotan del formato NO-DO, y de los significantes y significados que florecen a la luz de la relación entre ellos, para construir una imagen de la mujer que termina siendo concluyente en los films objeto de estudio. Por todo ello, y como cabría esperar si se quiere abordar con eficacia el propósito fijado, se hace necesario dibujar el marco histórico, económico y social en el que se desenvuelven las mujeres de la España de Franco.

3 Jauss lo denomina horizonte de expectativas (Jauss, 1986).

4 Esta idea estaría en consonancia con "la hipótesis, hoy aceptada entre muchos historiadores, según la cual, la tendencia general del franquismo fue, desde muy pronto desmovilizar más que movilizar" (Sánchez-Biosca, 2006: 259) huyendo de esta forma de cualquier motivo que pudiera provocar la agitación de las masas. 


\section{La mujer en la España franquista}

Finalizada la Guerra Civil, la gran empresa del Nuevo Régimen era la regeneración total de una nación nueva forjada en la lucha contra el mal (Casanova, 2015: 54). Se trata de reconstruir la patria a partir de la disolución de unos ideales que provienen de un período, el republicano, que se encarga de atacar las esencias tradicionales sobre las que se sustentan los presupuestos políticos de este periodo dictatorial. Así lo expresa el Profesor Julián Casanova: "En realidad, ese objetivo de redimir a España era el común denominador de las fuerzas políticas y sociales que se sumaron a esa "gran empresa", identificada más por lo que querían destruir -la República, el liberalismo, el comunismo- que por un acuerdo sobre la definición del nuevo régimen" (2015: 45).

Atendiendo a esa base nacional-católica en la que se fundamenta la ideología franquista, se inicia la tarea de recuperar una España Imperial que tiene como razón la construcción simbólica de la dictadura, basada, principalmente, en una imagen idealizada de Franco como militar, salvador y redentor, transmitida a través de los numerosos bustos, estatuas, fotografías e imágenes en movimiento que se difunden por todo el país ${ }^{5}$.

La restauración del Nuevo Régimen trae consigo, desde el comienzo, la sistemática represión de las mujeres y, por consiguiente, la abolición de los derechos igualitarios y de ciudadanía que se registran en el régimen democrático de la Segunda República.

Escribe la profesora Mary Nash (2015:191-194) que "el régimen franquista se fundó en un rígido sistema de género que marcó la subalternidad de las mujeres mediante un nuevo orden jurídico que sostenía una jerarquía de privilegio masculino [...] La ordenación de la nueva sociedad se fundamentó en el nacional-catolicismo, mientras la remodelación de la feminidad franquista se inspiraba en la Contrarreforma".

No se descubre nada nuevo al explicar cómo el franquismo, sujeto a modelos reaccionarios con un fuerte componente religioso, encuentra en la subordinación de la mujer uno de sus pilares más férreos a la hora de configurar su política ideológica, económica y social. Estos mecanismos, convenientemente actualizados y utilizados, provocan una serie de desigualdades, como venimos diciendo, sistemáticas y estructurales entre mujeres y hombres, que se hacen patentes incluso en épocas muy posteriores, reafirmando, como dice Lourdes Benería, "la posición de inferioridad de la mujer en lo que respecta a su lucha por la independencia económica" (Benería, 1997: 56).

Tanto se insiste en esta idea, que esa labor intensiva en cuanto a la política de género del régimen franquista, se ve refrendada por la creación de una legislación específica para la mujer. De esta forma, y con ellas recluidas en el ámbito doméstico, se pone fin a los avances alcanzados en la Segunda República en los que se reconoce a la mujer como ciudadana con capacidad para decidir de manera autónoma. Ya en el periodo bélico, desde 1936, en la zona nacional, se trabaja por anular toda la legislación republicana encaminada a afirmar la igualdad jurídica entre los sexos. Esta es sustituida por otra discriminatoria que trae consecuencias como la supresión de la coeducación en septiembre de 1936.

Precisamente, esa jerarquía de la que habla Nash se fundamenta, entre otros aspectos, en la desigualdad educativa entre hombres y mujeres sustentada por la Ley de Enseñanza Primaria de 1945 que permanece en vigor hasta 1970, y en la que se detallan los principios de separación de sexos y feminización de la enseñanza.

Las mujeres carecen de derechos políticos y civiles, y la legislación propicia que las jóvenes destierren, en su mayoría, la posibilidad de continuar sus estudios y de cualquier actividad vinculada al ámbito público quedando relegadas en un principio al hogar paterno, y más tarde al suyo propio bajo el yugo del varón. Nash nos recuerda al hablar de la estig-

5 Para obtener unos datos precisos del contexto histórico, político y económico durante la dictadura franquista, nos hemos basado en: (Payne, 1987), (Payne, 1997), (Tussel, 1999), Nielfa (2003), (Riquer, 2010). 
matización de las antifascistas que, "la retórica de la dictadura recuperó arcaicos arquetipos femeninos como Reina del hogar y Perfecta casada en sus esfuerzos para normalizar una nueva mujer franquista conforme al mandato de una feminidad de obligada y abnegada dedicación al hogar y a la familia, al servicio de la purificación y nacionalización de España" (Nash, 2015: 192).

A todo lo anterior conviene añadir que una vez concluida la Guerra Civil española, el gobierno franquista se propone una política encaminada a exaltar y glorificar los valores del mundo rural con el fin de acabar con el despoblamiento de estas zonas de España. Sin embargo, la introspección que supone el régimen político y económico en esos primeros años de la autarquía, no hace otra cosa que condenar a la miseria y al hambre a todo el campesinado. Esta situación resulta especialmente dura para las mujeres liberadas por el Estado de las fábricas y los trabajos prestigiosos y productivos que, lejos del discurso oficial, trabajan a miles en el campo diariamente ${ }^{6}$. Llegados ya los años cincuenta nos hallamos con la herencia de la etapa anterior y descubrimos valores que privilegian las jerarquías sociales y la diferenciación de sexos, aunque es cierto que a mediados de este década la situación experimenta un ligero cambio que encuentra su apoyo en una apertura de la política económica del país que repercute en una lenta recuperación demográfica y el incipiente desarrollo económico con la expansión de los sectores secundario y terciario.

No obstante, las mujeres siguen experimentando una vida de renuncias y de largas jornadas laborales, mal remuneradas en el mejor de los casos, que se prolonga hasta décadas posteriores. Incluso con la llegada del Plan de Estabilización en 1959, con el que se inaugura el desarrollismo y con él un cierto cambio de rumbo con respecto al trabajo asalariado femenino -consecuencia, por otra parte, de la demanda de mano de obra barata en relación a la mujer- se siguió manteniendo el estereotipo de mujer domestica, madre y esposa, sumisa y condicionada a la custodia del varón. Aunque la Ley de Derechos Políticos, Profesionales y Laborales de la Mujer de julio de 1961 reconoce a la mujer los mismos derechos que al hombre en los espacios señalados, desde las altas esferas de la Sección Femenina se hace constar que la mujer no puede ambicionar la igualdad. Sirva como ejemplo las palabras de Pilar Primo de Rivera: "En modo alguno queremos hacer del hombre y la mujer dos seres iguales; ni por naturaleza ni por fines a cumplir en la vida podrán nunca igualarse" (Nash, 2015: 212).

En todo caso, parece que la modernización que trajo consigo el aumento de capital en nuestro país fuera directamente proporcional a los cambios en torno al papel de la mujer en la sociedad española. No cabe duda de que las mujeres comienzan a romper con la subordinación y con la autoridad masculina, y que cada vez en mayor número acceden a la universidad y al mundo laboral ocupando puestos de responsabilidad. Sin embargo, resulta revelador el gran éxito que, todavía, en 1964 tiene la undécima edición del libro L'etern femení (1964), un libro que, como declara Mary Nash (2015:193) "expresaba un modelo de domesticidad incuestionable. Tenía un cierto aire modernizador, pero mostraba la función servil y de objeto de adorno de la mujer al servicio del marido".

Las acertadas palabras de Mary Nash nos permiten reconducir este estudio hasta la aproximación de la imagen de la mujer objeto, a través de la moda, en los primeros años del franquismo, una imagen que, algunos documentos históricos, como el Archivo NO-DO, han ido forjado en la memoria colectiva. Solo queda profundizar ahora en los pliegues del recuerdo para entender el papel desempeñado por la mujer en una sociedad, como decíamos

6 Aunque en 1940 en el sector agrícola los hombres constituían el 94,5\% estos datos no significaban que la mujer no realizase trabajos agrícolas, ya que cada 100 mujeres que trabajaban en el campo, 70 lo hacían en concepto de ayuda familiar, sin cobrar salario alguno, por lo que no figuraban en ningún tipo de censo. Consultar en: La mujer durante el franquismo, [online, consultado el 3/1/2017] http://www.vallenajerilla.com/berceo/ garciacarcel/lamujerduranteelfranquismo.htm 
más arriba, basada en arcaicos modelos patriarcales y unos principios de doctrina y moral católica que acabaron enraizándose e imponiéndose en todos los ámbitos de la sociedad española, tanto en el ámbito público como en el ámbito privado a partir de espeluznantes discursos como este: “¿Qué hermoso es el pudor y qué espléndida joya de la vida! [exclama San Bernardo] . ¡Que no sea pisoteado por fáciles atractivos del vicio, fruto corrompido de tan perniciosas libertades en el vestir y de la serie de inmoralidades que hemos indicado y que no podemos menos que lamentar!” (Boletín Oficial de la Diócesis de Pamplona: 204).

\section{Moda y virtud}

¡Qué modas tan indignas, tan atentatorias al pudor! ¡Pierna al aire hasta el muslo, brazos al descubierto hasta cerca del sobaco, escotes en el pecho y en la espalda, vestidos ceñidos al cuerpo de un modo inverecundo! ; así van peor que desnudas!. Con decretos como este, emitidos por el Padre Ayala ${ }^{7}$, la mujer española de los años posteriores a la guerra, debe posicionarse físicamente en el mundo. Estas palabras indican que uno de los poderes fácticos más importantes del aparato político del Régimen, la Iglesia Católica, descubre en la moda femenina un elemento más que influyente de la vida pública de la mujer. Por este motivo, desde la inmediata posguerra se comienza a trabajar con eficacia y eficiencia sobre la modestia y la austeridad que, como contrapartida a la inmoralidad, extravagancia y frivolidad, deben caracterizar a las decentes féminas españolas. Tal y como asegura Gemma Piérola, "obispos y prelados dedicaron numerosas cartas pastorales y campañas en pro de la decencia de la mujer, recomendando a estas una forma decorosa de vestir dentro de los cánones de la más estricta moral cristiana. Para ello, buscaron el asesoramiento de algunos seglares, para así poder llegar a la realidad y saber utilizar un lenguaje apropiado y claro" (2000: 45). En este sentido podemos comprender el papel único y primordial que juega la Sección Femenina, no solo en el ámbito del vestir sino en todos aquellos aspectos relacionados con el universo femenino, sobre todo, en la primera época franquista. Y es que, aunque no influyó, en ningún caso, en las decisiones del poder político, fue utilizada por el Régimen para desarrollar su proyecto sociopolítico, de manera que se convierte en el instrumento más eficaz de adoctrinamiento ideológico y socialización para las mujeres de posguerra.

Así, el aparato político del Régimen junto con la Iglesia idearon un plan, muy bien fraguado, en el que se pensó, incluso, en una normativa, respecto al modo de vestir femenino, que fuera difundida por todos los medios de comunicación adscritos al poder, de tal manera que, como asegura Gemma Piérola, "todas aquellas ideas fueran penetrando entre la masa de la población sin llamar demasiado la atención” (2000: 47). En este sentido, comienzan a surgir una serie de Revistas Femeninas que marcarán las pautas de conducta de la mujer en la España posrepublicana, basadas, como ya hemos visto, en la sumisión, el servicio y el sacrificio, unos valores que debe desarrollar desde su papel de esposa, madre y Servidora de la Patria. Entre ellas destacan títulos como: Medina, Ventanal, Bazar, Teresa o Consigna. La representación de la mujer en estas revistas seguía, al pie de la letra, todos los preceptos promulgados por este poder totalizador. Estas publicaciones se convierten así en puros entretenimientos con obligaciones para la mujer como decorar el hogar o realizar suculentos platos para sus esposos cegando, de este modo, el horizonte intelectual de las nuevas generaciones y apagando las ilusiones y los proyectos de aquellas otras que soñaron con la independencia.

De todas estas publicaciones nos interesa, especialmente, la Revista Medina ${ }^{8}$ por la influencia que esta edición tiene en cuanto a la ejecución y el formato de las secciones de

\footnotetext{
7 Recogidas en (Abella, 1984:164).

8 Es cierto que con anterioridad a esta revista existía una revista dedicada a las mujeres, La Moda y el Hogar, cuya publicación se remonta a 1909 y que se presenta atrasada en respecto a cualquier magazin europeo, pero nos interesa Medina, especialmente, porque fue creada ya en pleno periodo autárquico a partir de presupuestos marcados por la Sección Femenina.
} 
moda que aparecen en los NO-DOs de más de una década desde la aparición del Noticiario Cinematográfico Español. La revista fue creada en 1941 y, como muy bien explica Alfonso Pinilla, "cumple a la perfección las funciones de adoctrinamiento y socialización que el Régimen concede a la Sección Femenina. Dirigida fundamentalmente a las mujeres de la organización, y repartida mensualmente entre las jefes locales y provinciales, Medina se convierte en la guía de la mujer nacionalsindicalista que precisa el nuevo Régimen. Abnegada y fiel a la obra de Franco, responsable de su hogar, esposa y madre perfecta, el prototipo de "mujer Medina" corresponde al modelo de mujer fascista que todo régimen totalitario desea construir" (2006: 156). Efectivamente, Medina insiste en que la mujer debe llevar una vida abnegada, con un alto sentido del recato y el pudor que debe verse reflejado en todo los aspectos de su vida, incluida la moda. Se trata, en definitiva, de construir, en relación a la mujer, una manera de estar en el mundo. Por eso, desde el comienzo de su aparición, la revista cuenta con una sección denominada Modas. En este apartado la revista explica, con lujo de detalles, cómo la mujer debe ser elegante y encantadora sin caer en la extravagancia. Se propone un modelo femenino sofisticado y "moderno"9 que, paradójicamente, era inalcanzable para la mayoría de las mujeres españolas de posguerra preocupadas más por alimentar a sus hijos que por su aspecto exterior.

Con lo cual, nos encontramos con un discurso artificioso que permanecerá, igualmente, en el NO-DO, con la idea de distraer al máximo a la población y alejarla de la dura realidad en la que se hallan inmersos. Así, desde la Sección Femenina, se promulgan una serie de directrices que marcarán los senderos de la moda femenina tanto en la prensa escrita como en cualquier otro medio de comunicación, incluido el noticiario objeto de estudio ${ }^{10}$. Por eso nos parece oportuno destacar todavía el papel destinado a la radio en el sentido que nos ocupa, pues se sigue ajustando, indiscutiblemente, a los presupuestos de la prensa escrita y concuerda, como veremos, con lo que propone NO-DO. Y es que, como la mujer estaba recluida en el ámbito doméstico, la programación dirigida a ellas debía centrarse en la vida del círculo familiar, de tal manera que las emisiones de Radio Nacional de España basaban sus contenidos en la belleza, el hogar y la familia, tratando aspectos como la moda, la cocina, los hijos y la crónica rosa. Por eso, en los primeros años de posguerra se evidencian la presencia de algunos programas, limitados al ámbito nacional y regional, como Hora femenina o Mujer y Hogar, en los que "se manejaban un abanico de temas bastante limitados: consignas y frases de José Antonio Primo de rivera, moda, consejos a la mujer y aspectos folklóricos de la geografía española" (Gil Gascón y Gómez García, 2010: 136).

Pues bien, el 4 de enero de 1943, e inmerso en este pobre escenario de libertad, hace su aparición en el panorama español el NO-DO. Desde el comienzo de la emisión del Noticiario Cinematográfico Español hemos rastreado la presencia de una sección, Modas (Fig. 1), que se repite en numerosas ocasiones y que, sin duda, el Noticiario rescata de la revista Medina, pues recibe el mismo título que esta otorga a todo lo relacionado con la moda y la belleza femenina de estos primeros años de la dictadura franquista. Según la investigación que hemos llevado a cabo, desde 1943 hasta 1948 la sección Modas aparece ocho veces al año en ocho noticiarios distintos, excepto en el año 1945, en el que solo se muestra en dos ocasiones y en 1946, año en el que su presencia se reduce a cuatro noticiarios. Así mismo, hemos comprobado que esta sección está presente, si cabe con más fuerza a partir de 1950 hasta la desaparición de NO-DO.Además, hemos de señalar que desde 1947 la Revista Imágenes incluye un número al año dedicado a la moda, con una duración de unos diez minutos aproximadamente, que estará presente hasta 1968, un año antes de su desaparición ${ }^{11}$.

9 Teniendo en cuenta siempre la estética y los valores fascistas.

10 Para profundizar en la construcción del universo femenino propuesto por la Sección Femenina y la presencia de esta organización en el NO-DO hemos consultado: Ramos Lozano, P. (2013).

11 Desde 1945 se publica esta revista con periodicidad semanal. Se componía de documentales de unos diez 


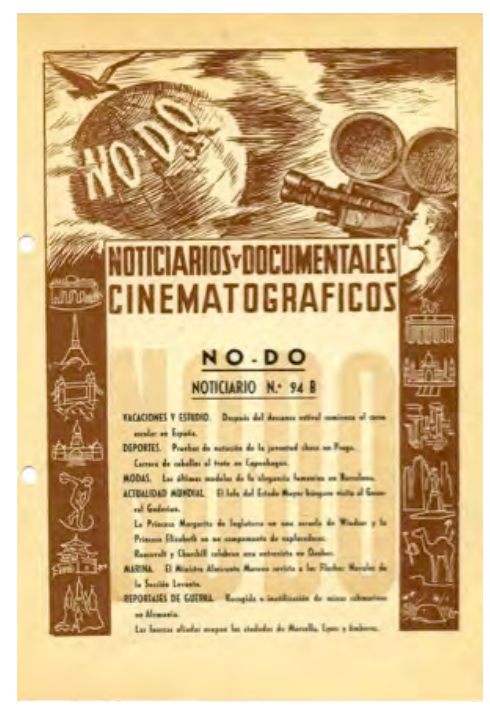

\section{Imagen. 1. Programa de mano. NO-DO No 94}

Una vez apuntados estos datos cuantitativos solo nos quedan por definir los elementos más significativos y las singularidades de la moda femenina que aparece en NO-DO durante los años más enérgicos de la dictadura franquista.

\section{El poder y la sugestión de la Elegancia femenina}

Decimos femenina y decimos bien, porque una de las principales características que determina el mundo de la belleza en el NO-DO de los primeros años es que las novedades relacionadas con la moda no solo están dirigidas a las mujeres sino que, además, están protagonizadas por ellas. Son raras las ocasiones en las que el vestir masculino se revela como principal. Cuando se desvela alguna noticia en este sentido nunca se muestra aislada, por el contrario, se presenta vinculada al universo femenino. Al igual sucede con la moda infantil representada, en su mayoría, por las niñas del futuro. La explicación a este hecho resulta significativa a la vez que evidente, y es que, en el comienzo de la dictadura se traslada a la mujer un mensaje explícito, en cuanto a la necesidad de cuidar el cuerpo y el aspecto físico, con el fin de que cumpla con su función de esposa y madre, por eso ha de atender a su salud y a su imagen, sin descuidar, bajo ningún concepto, las, en ocasiones, monótonas tareas del hogar: "proponemos [dicen desde la Sección Femenina] una ropa para ama de casa muy alegre, con muchos colores y contrastes, que cambiará las a veces molestas tareas, en divertido entretenimiento"12. No podemos olvidar, como dice Margarite Rivière, que "la prensa, en general, tiene una importante función en la proposición de modelos de conducta y de orientación del público hacia determinados objetivos. Concretamente, la prensa dirigida a las mujeres -o cuyo público son mujeres principalmente- cubre la importante función de servir de vehículo educacional de sus lectoras [o espectadoras en este caso]. La prensa femenina española, a través de sus secciones de modas, propone constantemente a las mujeres españolas, no tanto una sucesión de fotografías de modelos como una colección de modelos de actitudes y conductas que forzosamente han de incidir en el comportamiento posterior de las lectoras de tales revistas (1977: 137).

En este afán por generar una imagen impecable, a la vez que austera y pudorosa, de la

minutos de duración, de algunos de ellos nos ocuparemos en un momento posterior de nuestra investigación. 12 “Limpieza, belleza y alegría”. Medina, Mayo 1943, n 113, p. 24. 
mujer surge la consabida elegancia femenina, una constante que se repite en los distintos medios de comunicación. Solo hay que atender a la prensa escrita, los espacios radiofónicos o los programas de mano de los noticiarios de este periodo, para constatarlo. De este modo, en el NO-DO se dan cita numerosos títulos referidos a las noticias de moda en los que se introduce al lector/espectador en el mundo de la elegancia, a saber, Exhibición de modelos de la elegancia femenina en Estocolmo (Not. $N^{\circ} 41 B, 1943$ ), ultimas creaciones de la elegancia femenina británica para la moda estival (Not. $\mathrm{N}^{\circ} 24 \mathrm{~B}, 1943$ ), Desfile de los últimos modelos de la elegancia femenina en una casa de Bruselas (Not. No 21 A, 1943). Las últimas creaciones de la elegancia femenina en Suiza (Not. 8, 1943), Las última creaciones de la elegancia femenina en Bruselas (Not. $N^{\circ} 63$ A, 1944), La moda de hoy. La elegancia femenina en Bruselas (Not. No 362 A, 1949), La elegancia femenina. En el Caribe Hilton de Puerto Rico. Exhibición de la moda de invierno (Not. № 563 B, 1953), Exhibición en Italia. La elegancia femenina (Not. № 814 B, 1958) o Modelos extranjeros llegan a Madrid. Exhibición de la elegancia femenina con fines benéficos en el Palacio de Liria (Not. $\mathrm{N}^{\circ} 850$ A, 1959 $)^{13}$. En otras ocasiones es la voz del narrador o narradora la que se hace eco de tan primordial atributo y en algunas más, la elegancia aparece asociada a la casa de modas que realiza el evento o al propio evento, así se puede apreciar en títulos como este: "Exhibición de modelos de peletería en una elegante casa de Barcelona" (Not. 154 A, 1944). Este hecho se repite hasta el año 1960. A partir de entonces, los títulos de los programas de mano se vuelven más directos y objetivos ${ }^{14}$, e incluso los narradores emplean otro tipo de adjetivos para describir los modelos que portan las maniquíes ${ }^{15}$ en los distintos desfiles. Es cierto que se resisten a desechar el elemento que había venido caracterizando su discurso hasta el momento, por eso buscan sustitutos próximos a la idea de elegancia como podemos apreciar: "Feminidad, ligereza y alegría de colores, son las características de la moda francesa de primavera" (Moda, fraude y contrabando, Revista imágenes, Nº 795, 1960).

$\mathrm{El}$ hecho de que se vayan produciendo estas modificaciones, tanto en el discurso hablado como en el escrito, está sujeto, sin duda, a los cambios que experimenta el país durante lo que se ha denominado periodo desarrollista. Existe ahora la necesidad de lavar la imagen externa de España, por tanto, se produce un debilitamiento del mensaje adoctrinador, aunque no se abandone, en ningún caso, el lenguaje sexista que caracteriza las noticias y documentales referidos a la moda. Esta empresa resulta fundamental por cuanto la manera de vender el producto nacional entronca con la pervivencia de la imagen y de la visión sesgada y distorsionada, desde el punto de vista cultural, político y social, de la mujer, difundida a través de NO-DO y otros medios de comunicación al servicio del Régimen, cuya prolongación en el tiempo superó a la dictadura franquista.

En todo caso, tratando de dotar de sentido a lo que subyace bajo la idea de elegancia, defendida desde instituciones como la Sección Femenina o la Iglesia, habremos de tener en cuenta que en los años veinte del pasado siglo, precisamente cuando la mujer comenzaba a recorrer el camino hacia la igualdad y la libertad se produce en el mundo de la moda, proveniente de París, un verdadero acto político con la llegada a la historia del diseño de Coco Chanel. Con sus vestidos de corte sencillo, sus peinados a lo garçonne y una imagen femenina andrógina, la mujer de los años veinte, aunque fundamentalmente ama de casa, había experimentado durante la $1^{\mathrm{a}}$ Guerra Mundial una forma de independencia; las mujeres habían tenido que arreglárselas solas mientras los hombres luchaban en el frente. Esta forma

13 Hemos seleccionado algunos números de manera aleatoria para dejar constancia de esta idea pero podemos afirmar que se encuentra presente en la sección de moda hasta 1959, año en que comienza el periodo desarrollista. 14 Estos son algunos de los títulos: "Una nueva moda femenina. Invención de los peluqueros en Milán" (Not. 933 B , 1960); "El XLII salón de la moda española. Exhibición barcelonesa de la cooperativa de alta costura" (Not. 980 C, 1961); "El tercer desfile de la moda española de la piel. Lo preside Doña Carmen Polo de Franco" (Not. 1042 B, 1962); y así sucesivamente.

15 Así suelen referirse los narradores a las modelos. 
de emancipación se traduce en una seguridad que no estarían dispuestas a perder, ni siquiera por la inercia de una sociedad marcada por numerosos presupuestos anclados en modelos patriarcales. Dicho arquetipo femenino, que reacciona, en cierta medida, contra la elegancia clásica, del que participan muchas de las mujeres de la Segunda República, es el que se pretende abolir desde los poderes totalitarios en general y en particular en la dictadura franquista. No debemos olvidar que muchas de las mujeres de posguerra fueron humilladas por haber transgredido los límites de la feminidad tradicional, por eso no es de extrañar que encontremos afirmaciones como la que sigue: "Todo tiene disculpas en asuntos vestuarios [...] menos el mal gusto, que es perfectamente susceptible de dominio por la obediencia y por la voluntad. La elegancia no es una cuestión de adornos, de lujo ni de dinero. Es simplemente una armonía de todos los factores que están a nuestro alcance"16.

Es cierto que los años cuarenta se caracterizan por la austeridad, la modestia y la sobriedad en el vestir femenino debido, lógicamente, a la escasez provocada por la Segunda Guerra Mundial, y en el caso de España por los atroces años de la posguerra, pero también es verdad, como explica Francisco de Sousa que, "mientras los países beligerantes en la Segunda Guerra Mundial tras el fin de la contienda tendrán una recuperación más acelerada del interés por la moda, propiciado por la reconstrucción de sus sistemas económicos mediante la iniciativa norteamericana materializada en el plan Marshall, del que España queda excluida, nuestro país va a permanecer en gran parte aislado de las innovaciones del mundo del traje" (2007: 213). Solo hay que atender al desarrollo de la moda en nuestro país vecino. Efectivamente, las francesas, dispuestas a mantener su reputación como las mujeres mejor vestidas del mundo desarrollaron un estilo extravagante para demostrar su independencia utilizando el rojo oscuro para los labios y el azul, blanco y rojo para los vestidos. Aunque algunos diseñadores y diseñadoras como Pierre Balmain o Jeanne Lanvin apuestan por la elegancia y el refinamiento, los cortes de sus vestidos se caracterizaban por las líneas rectas y sencillas que dibujaban, a la perfección, la silueta de la mujer. Igualmente, en la década de los cincuenta, diseñadores como Dior, que continúan apostando por la belleza en sus creaciones, no renuncian, en ningún caso, a definir y estrechar la cintura y marcar en sus creaciones la zona del pecho y, sin embargo, en España, caminamos en sentido opuesto.

La elegancia en nuestro país viene marcada por la sobriedad, el recato y el tradicionalismo. Por eso, en aquellos pocos noticiarios de los primeros años en los que se muestra la moda que genera nuestro país, observamos cómo los diseños concuerdan con la estética que se transmite a través de las revistas destinadas a las mujeres, de modo que se presenta una silueta femenina rígida, con hombros armados y rectos, vestidos cortados en la cintura -para que la figura de la mujer se defina levemente- y con largos por debajo de la rodilla. Véanse algunos noticiarios como el que sigue: Modas: Los últimos modelos de la elegancia femenina en Barcelona (Not. 94 B, 1944) (Imagen 2). En él podemos observar cómo la cámara, en un ligero contrapicado pero distante, recoge a las distintas modelos que van apareciendo en la pantalla para lucir sus trajes de día y de noche. En muy raras ocasiones se produce un acortamiento de la escala, y cuando sucede lleva aparejado el comentario pertinente del narrador refiriéndose a algún detalle del atuendo que porta la modelo, como se puede observar (Fig. 2): "Una casa de modas de Barcelona, ofrece los más recientes y originales modelos para la elegancia femenina de otoño e invierno. Después del abrigo beig, con bolero castor y fieltro marrón, se exhiben tres elegantes conjuntos para tarde. Llega el turno a los trajes de noche, admiremos este color marrón con bordados; este negro, con encajes de sobria y fina distinción. Otro modelo en tafetán rosa y negro. Traje de noche de tul con encajes negros. Las señoras, ¿han elegido ya?”. Vemos pues cómo, predominan los tonos poco llamativos, de modo que los colores pálidos conviven con los sobrios. Estos, unidos al uso de las botonaduras militares y los cuellos cerrados, acrecientan la deseada austeridad y elegancia.

16 Medina, revista de la Sección Femenina, 10 de mayo de 1942. En: Otero (2004:158). 


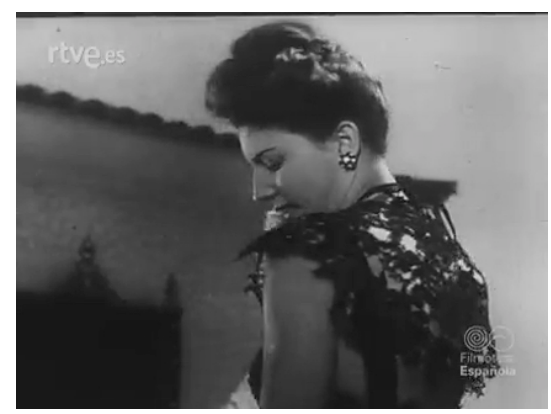

Imagen 2. Modas: Los últimos modelos de la elegancia femenina en Barcelona

La sobriedad, el recato y, sobre todo, esa elegancia a la que nos venimos refiriendo aparecen en NO-DO, incluso, cuando la noticia llega desde París. En este sentido, es reseñable la manera en la que en el Not. No 1 (1943), muestra, Los nuevos peinados de París. La mujer parisina es presentada aquí por la cámara como un verdadero maniquí, con gesto hierático, del que solo se muestra la cabeza desde numerosos ángulos, mientras que la voz off, figura indispensable en el desarrollo de $\mathrm{NO}-\mathrm{DO}^{17}$, explica cómo "las actuales corrientes del arte peluqueril femenino vuelven en París a los cánones clásicos [...]". De esta forma, se da a entender que, hasta la ciudad menos conservadora en lo que se refiere a la moda femenina, pionera en la lucha por la igualdad y la independencia de la mujer, mira al pasado más clásico y deja atrás aquellas locas ideas del París de los años veinte.

En este sentido, llama la atención, poderosamente, que la primera noticia destinada a la moda femenina que aparece en el Noticiario Cinematográfico Español arranque de un país extranjero y, lo que es más importante, que este hecho se mantenga como una constante en los NO-DOs del periodo autárquico ${ }^{18}$. Incluso, los primeros documentales de la Revista Imágenes en relación a la moda, proceden del ámbito anglosajón, de tal forma que, hasta la voz over se mantiene en el idioma original y no se dobla al español. La explicación a este hecho es bien sencilla. El aislamiento que, en todos los sentidos, experimentó España durante la primera etapa de la dictadura franquista propició el hecho de que apenas se modernizara la industria textil. No existían las grandes boutiques y la ropa la confeccionaban las modistas, costureras, y amas de casa inspirándose en las revistas nacionales de la época ${ }^{19}$. Como resultado nos encontramos con que solo uno de nuestros diseñadores, Balenciaga -al que se referirán en algunas ocasiones en el Noticiario- alcanzará el reconocimiento internacional. La moda, fue una perseguida más de Régimen; todo lo que no se ajustara a los preceptos tradicionalistas que se marcaban desde el poder era perseguido y arrasado. Según ellos se buscaba el sello de lo hispánico, tal vez ese fuera el motivo por el que el maestro Balenciaga contara, además de todos los éxitos cosechados fuera de nuestras fronteras, con

17 Rafael Tranche explica cómo el narrador en NO-DO "asumirá competencias similares a las de otros noticiarios: conducir la atención del espectador a través de la imagen (e incluso traducir los elementos sonoros que no se reproducen). Frente a otros casos, siempre se utilizará un único locutor por noticiario y su identidad no se dará a conocer. Además hay que destacar las escasas ocasiones en que la voz del narrador conseguirá marcar un registro (en términos fonéticos) distinto al de la locución convencional. Los énfasis de arenga o exaltación para interpelar o soliviantar al espectador se reservarán para contadas ocasiones" (2006: 121).

18 Así, nos encontramos con: "Elegancia femenina en Rio de Janeiro y Nueva York" (Not. 179 A, 1946); "Elegancia femenina en Estocolmo" (Not. 41 B, 1943); "Desfile en Bruselas" (Not. 21 A, 1943); "Desfile en buenos Aires" (Not. 18, 1943); "Desfile en Copenhague" (Not. 11, 1943); y un largo etcétera que podemos rastrear hasta bien entrados los años 60 .

19 La sección de moda era tan importante en estas revistas que incluso se dedicaba una parte de la misma a publicar patrones de costura que eran muy bien recibidos por las amas de casa, pues una de sus posibles obligaciones era la costura. 
el beneplácito nacional, porque a pesar de innovar en sus diseños con una nueva silueta para la mujer que, sin duda, revolucionaría el mundo de la moda femenina, conquistó al público de París con colecciones de marcado acento historicista inspiradas en la obra de Velázquez, Goya o Zurbarán en el uso de los colores, abullonados, mantillas, peinetas o encajes.

No obstante, lo que se da a entender a las ciudadanas españolas, a partir de los medios de comunicación, es que nuestro país se encuentra a la cabeza de cualquier otra capital europea, también, en el ámbito del vestir femenino. De ahí que NO-DO se haga eco de algunas noticias en las que se publicita nuestra forma de vestir a la mujer de la siguiente forma: "Una importante casa de modas de Barcelona, presenta las nuevas invenciones de la elegancia femenina, que nada tienen que envidiar a las mejores extranjeras [...] La mantilla española es utilizada como chal para salida en los trajes de noche, una muestra más de que no hace falta buscar fuera de nuestras fronteras lo que puede constituir el mayor encanto de la indumentaria en la mujer" (Not. N 215 B, 1947). En otras ocasiones se alude a la autonomía de España en la creación de la elegancia femenina mostrando el trabajo de algunas modistas nacionales, tal es el caso de las hermanas Huertas que han conseguido algunos premios de carácter provincial y nacional (Not. 254 B, 1947).

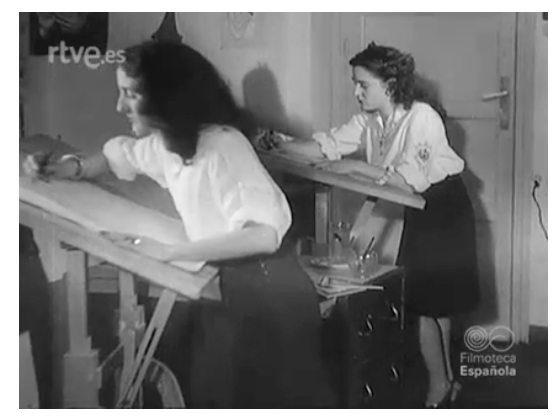

Imagen. 3. NO-DO.

\section{Moda y sumisión}

El camino de la sumisión de la mujer estaba trazado. Este fue uno de los objetivos principales de la Sección Femenina. Lo que se esperaba del sexo débil -así acostumbraban a llamarlo- era docilidad y sacrificio, algo que no suponía ninguna dificultad teniendo en cuenta que las mujeres de la dictadura fueron despojadas de todo tipo de independencia y libertad. La subordinación comenzaba, como hemos dicho más arriba, en la casa paterna y continuaba con la celebración del matrimonio católico. Acto seguido, la mujer quedaba subyugada al dominio del esposo. Este ciclo vital sería completado con la maternidad, finalidad máxima de su existencia. Con este futuro prometedor, a las chicas se les enseñaba desde muy pronto a agradar para conseguir un marido que se convirtiera en su seguro de vida, algo que no resultaba del todo fácil porque la población femenina, sobre todo después de la guerra, era más numerosa que la masculina, así que, la tarea en la lucha por alejarse de la soltería, muy mal vista por cierto, resultaba arduo complicada. Por eso no es de extrañar que, el NO-DO, a través de sus secciones de moda influya, decididamente, en alentar a la mujer para que culmine con éxito lo que debería ser la ilusión de su vida: el matrimonio. La primera marca que detectamos al respecto se produce en el año 1943 en el Not. 41 B: Modas. Exhibición de la elegancia femenina en Estocolmo ${ }^{20}$. Como es habitual, una narradora ${ }^{21}$ describe los vesti-

20 En este trabajo se tratan temas que se presentan como constantes en el NO-DO aunque, por una cuestión de extensión del mismo, hemos realizados catas que nos permiten ejemplificar las ideas que queremos desarrollar. 21 Llama nuestra atención cómo para comentar las secciones de moda es frecuente recurrir a una mujer. Esto 


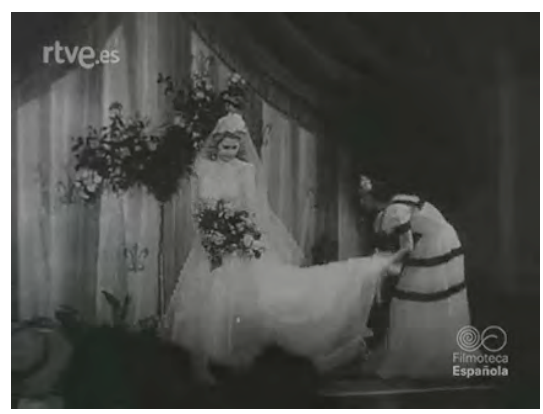

Imagen. 4. Modas. Exhibición de la elegancia femenina en Estocolmo.

dos de noche que portan las modelos, haciendo hincapié en la elegancia femenina, hasta que el desfile se cierra con el vestido de novia. Según la voz off, se trata "del vestido de novia, que sin grandes variaciones, concreta y sintetiza la ilusión de todas las muchachas solteras, deseosas de que llegue el instante de vestir esta vaporosa indumentaria". La prenda en cuestión responde al canon estético previsto basado en el recato y la delicadeza que proporciona el tul de seda y que convierte a la novia en una delicada flor (Imagen 4).

Otro desfile, también en Estocolmo, se vuelve a hacer eco de la misma idea. Esta vez es un narrador quien anuncia los vestidos matrimoniales: "Y el sueño de todas las muchachas casaderas, la gala nupcial, a la vez que las chicas, vestidas de novia, se desplazan por la pasarela" (Not. 57 B, 1944). También en 1944 nos volvemos a encontrar con otra noticia de similar características. Esta vez se trata de un desfile de novios de guerra en el que distintas parejas, ellas con trajes de tul o encaje, y ellos con uniformes militares, muestran su felicidad en la pasarela por tan deseado acontecimiento sin necesidad, incluso, de que una voz narradora describa al espectador los hechos (Modas. Un curioso desfile de "novios de guerra". Not. 62 B). Asistimos así a una constante que se repite a lo largo de todo el periodo autárquico y se extiende hasta bien entrados los años sesenta, así podemos demostrarlo con reportajes como Panorama de modas (Revista Imágenes, № 865, 1961). En este documental, las muchachas aparece en la pantalla subidas a extraordinarios coches de lujo ${ }^{22}$ que abandonan después para mostrar sus vestidos, el último de ellos, el traje nupcial. Según la voz over -esta vez femenina-, "antes de que el desfile termine, una sorpresa con la que sueñan todas las muchachas, el traje blanco de la novia". Igualmente, conviene vincular el matrimonio con su consecuencia más inmediata, la maternidad. Por eso, se realizan reportajes, como este de 1948, en el que un grupo de muchachas, pasean sus alegres vestidos estivales y trajes de baño, rodeando una piscina, mientras que una de ellas, al fondo de la composición y el en centro de la misma, juega con su hijo animadamente (Modas. La elegancia femenina francesa. Exhibición de modelos estivales. Not. 293 B) (Imagen. 5).

Pero las señales de acatamiento se siguen sucediendo en estos documentales que, como vemos, terminan siendo el reflejo de la sociedad patriarcal que los produce. De este modo, nos encontramos con noticias en las que la mujer, dependiente de la economía masculina, es mostrada como un objeto decorativo y superficial mimada por el bolsillo de su esposo. Los narradores ${ }^{23}$ se jactan de ello con palabras como las que siguen: "Una importante peletería barcelonesa, exhibe para las espectadora de NO-DO y también para los espectadores, en

no sucederá en ninguna otra sección de NO-DO. En todas las demás los narradores serán voces masculinas muy conocidas de este país, como la de Matías Prats.

22 Es frecuente encontrar escenografías de este tipo en las que las modelos son mostradas como objetos de deseo para los hombres, igualándolas a estas maquinarias sobre ruedas vinculadas a lo masculino.

23 En la mayoría de las ocasiones las noticias sobre moda eran narradas por una voz femenina que denota el carácter machista y sexista de la noticia, porque en ningún caso una noticia referida, por ejemplo al futbol deporte masculino por antonomasia- era retransmitida por una mujer. 


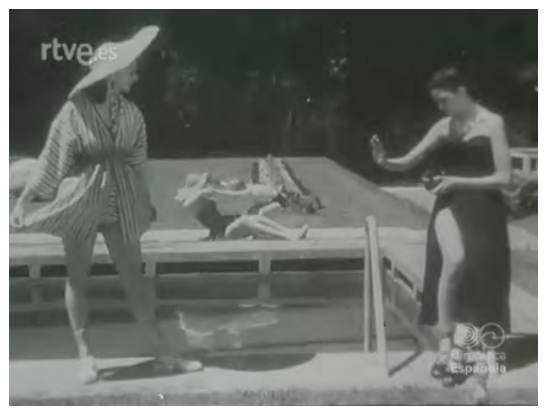

Fig. 5. Modas. La elegancia femenina francesa. Exhibición de modelos estivales.

cuyos cálculos económicos entraba el deseo de hacer un regalo a su esposa, esta magnifica colección de abrigos de pieles con los últimos modelos de la temporada [...] Qué, ¿se decide usted, señor? No lo dude" (Modas: Desfile de modelos con las últimas novedades de peletería en Barcelona. Not. 50 A, 1943); "La palabra moda encierra diferentes significados. Para las señoras entraña el deseo de lucir un vestido nuevo con arreglo a la caprichosa dictadura de los modistos. Para los caballeros, la palabra moda se traduce, muchas veces, en un desequilibrio entre los gastos y los ingresos del presupuesto del hogar doméstico [...]" (Modas. Creaciones en un salón británico. Not. 10, 1943); "Progresa la historia de la moda en Suiza y en Zúrich se realiza una exhibición de modelos donde las espectadoras pueden admirar las últimas creaciones de la elegancia femenina y tomar nota para sus vestidos, con la benévola sonrisa en unos casos y en otros con la sospechosa alarma de padres y esposos" (Not. 8, 1943).

Estos comentarios se hacen extensivos a los documentales que se realizan en la Revista Imágenes y estarán presentes hasta el último de ellos, en 1968, como podemos observar: "Hace algún tiempo asistí a una pasada de modelos que resultó. Además, había una orquesta que acompañaba muy bien. Los conjuntos de piel, impresionantes. Le dije a Jean Pierre -mi marido se llama Jean Pierre-, que preguntase el precio, y ¡de repente se acordó que tenía una entrevista con un señor muy importante! ¡Como si yo fuera tonta [...]!” (La línea y la moda. Revista imágenes, $\left.N^{\circ} 1205,1968\right)$. Es evidente que la narradora utiliza un tono distendido, e incluso humorístico, para dar cuenta de su dependencia haciendo cómplice así al espectador. Esta manera de conducir la atención no resulta una excepción en los reportajes de moda de la Revista imágenes, porque tal y como ha comentado Rafael Tranche refiriéndose a las voces off de NO-DO, "en ocasiones, el narrador se valdrá de artificios retóricos para tomar distancia frente a lo narrado. Una posibilidad será aplicar el humor a través de determinados giros y juegos de palabras introducidos en los comentarios. La mayoría de las veces este criterio no parte de la concepción misma de la noticia, sino que se imposta como un efecto paródico a partir de las imágenes" (2006: 121). En este sentido, es fácil deducir que la mujer tiene asumido su rol desde el momento en que, hasta la propia narradora, se muestra subyugada a la economía de su esposo. Por ello, se convierte en un procedimiento común, e incluso se crean divertidas discusiones entre una narradora y un narrador -que en ocasiones actúan como marido y mujer- en las que no faltan los comentarios jocosos y machistas. Así podemos comprobarlo en el № 601 de la revista (1956), titulado: Arte y moda: Alta costura en España. En el documental se intercalan una voz femenina y otra masculina, a la vez que se van sucediendo en la pantalla imágenes de esculturas clásicas que ilustran las siguientes palabras:

Narrador: Dice una leyenda -que nos acabamos de inventar ahora mismo- que a Venus se le cayeron los brazos de tanto probarse modelos. 
Narradora: La historia ha desautorizada esta versión. La verdad es que Venus, en sus momentos de pudor, se ponía estas honestas túnicas.

Narrador: Sí. Y en cuanto empezó a manejar trapos perdió la cabeza.

O en este otro reportaje de 1957 titulado Comentando la moda ( $\mathrm{N}^{\circ}$ 664), en el que queda claro quién dirige la acción, a la vez que se constituye en una demostración del poder del hombre hacia la mujer. Solo hay que atender a las siguientes palabras para comprobarlo:

Narrador: ¡Que deprisa pasa todo! Esta es la consideración que nos sugiere la evolución de la indumentaria femenina que llega has nuestros días.

Narradora: Bueno, no es para tanto, no es para tanto. Yo creo que todo vuelve. Narrador: Cállate y deja hablar al locutor.

Locutor: Si usted quiere, señora, le cedo el puesto [...]

Narrador: Muy amable señor locutor, pero de ninguna manera.

Narradora: De esto las mujeres sabemos más que los hombres.

Narrador: Qué buena oportunidad para callarse ¡Mira, mira! ¿Quién dibuja los vestidos? Anda.

Narradora: Y, ¿qué haría el modisto sin la mujer, eh? Anda, anda, convéncete [...]

Narrador: Pues a mí lo que me gusta son los coches. A las modelos las veo demasiado jóvenes.

Narradora: Es que los modelos que lucen son propios para su edad y también para el deporte. ¡Oh, ese gorro de Robín de los bosques es un sueño!

Narrador: Pero lanzando la flecha no tiene nada que ver con Guillermo Tell. Mira.

Narradora: Lo que más me gusta es la pluma.

Narrador: ¿Te atreverías a ponerte eso?

Narradora: Si tuviera sus años [...] Ya lo creo.

Narrador: Pero no los tienes.

Narradora: Qué me dices de las ciclistas.

Narrador: Dedícate a contemplar los vestidos.

Narradora: Son muy monos. No están nada mal.

El texto pone de manifiesto la idea de desigualdad y sometimiento a través de numerosos detalles, pero principalmente asociando a la mujer con lo bello, lo superficial y la eterna juventud, mientras que las acciones del intelecto -como el desarrollo del diseño de los trajes- se destinan al hombre.

\section{Moda y deporte}

Uno de los grandes cambios educativos planteados en la dictadura franquista, tras la revisión del sistema formativo republicano, fue la introducción de la asignatura de Gimnasia como materia obligatoria en la Enseñanza Media. Cristina Machado y Juan Manuel Fernández explican cómo "esto conllevó un cambio significativo en la consideración de la Educación Física, caracterizada por la acción pedagógica militarista, bajo un tono de adoctrinamiento autoritario, rígido y disciplinario que orientó la materia hacia la regeneración de la raza" (2015: 209).

En el caso de la mujer, fue la Sección Femenina la encargada de su formación también en esta materia, bajo la premisa del servilismo. Así se refieren a ello: "Cada una de las camaradas al encuadrarse en Educación Física cumple con un deber moral y "sirve" [...] Nuestras chicas "sirven" cuando juegan, "sirven" cuando hacen gimnasia, "sirven" cuando 
alegre, caminan en fila india por una ladera” (Sánchez, 1990: 27). Ciertamente la Sección Femenina se ocupa de aclarar que una de sus preocupaciones fundamentales en cuanto a lo que se refiere a la formación de las camaradas de la Falange, la constituye la sanidad y la higiene del cuerpo. "La mujer, por cuanto tiene encomendada una formación educadora [dicen] inicial en la vida del niño, por madre, necesita, para desempeñarla, de una preparación justa. La educación física es, en este sentido, una de las enseñanzas que está obligada a recibir, como mujer de un Estado fuerte y sano. La higiene, la gimnasia y el deporte hacen de cada una de nosotras esa mujer sana y limpia moralmente que el Estado quiere para madre de sus hombres del porvenir" 24 . Pero, este interés promulgado desde la Sección Femenina para el cuidado del cuerpo debía basarse en el establecimiento de unos conceptos adecuados a su sexo y que se alejaban, sustancialmente, del ejercicio masculino. De tal manera que la práctica de algunas actividades físicas, tales como el atletismo, el fútbol, el rugby o montar en bicicleta, se catalogaron como contraproducentes tanto desde el punto de vista de la salud o por considerarse poco femeninas. En cambio, se potenciaron otras como el voleibol, el balonmano, el hockey, la natación, el montañismo, el esquí y el tenis. Este determinismo sexista se vio acompañado por otro de carácter clasista, ya que la práctica de los deportes asignados a ellas requerían de un poder adquisitivo imposible para la mayoría de la población.

En todo caso, y reconduciendo el tema hacia el objeto de nuestro estudio, el uso de la correcta indumentaria deportiva, según Machado y Fernández, "presentó una gran preocupación por parte de la Sección Femenina, tanto para realizar Educación Física, como para la práctica de actividades deportivas. Estas debía llegar por debajo de las rodillas, la utilización de pololos para que no se les viera las piernas al realizar la actividad y las mangas debían de ser cortas por los brazos y sin escote" (2015: 216).

En este sentido, el NO-DO en su sección de moda, al igual que cualquier otro medio de comunicación destinado al vestir femenino de la época, juega un papel fundamental en cuanto a la difusión de las ideas y el mensaje adoctrinador promulgado por la Sección Femenina y supervisado por la Iglesia a través de las Juntas Provinciales del Patronato de la Protección de la mujer. Las primeras noticias referidas a la indumentaria femenina para el deporte aparecen en NO-DO en 1948 en un reportaje titulado, Los modernos equipos para nieve y deporte invernal en Seattle. En este documental, un narrador de habla inglesa ilustra al espectador sobre las últimas novedades deportivas para las mujeres (Not. 261 A). A partir de 1950 este tipo de noticias se suceden dotando de una especial relevancia a los deportes de invierno ${ }^{25}$. De igual modo, la Revista Imágenes se convierte en una ilustradora fundamental de los contenidos que venimos apuntando. Solo hay que detenerse en la cabecera, destinada a estos reportajes de moda, con la que dicha revista inicia su andadura. Al ritmo acelerado de una marcha militar, los distintos planos que se suceden en la pantalla, mediante encadenados, cierres en iris u otros elementos cinematográficos, muestran a distintos grupos de chicas en formación, que se encuentran practicando diferentes actividades deportivas, mientras el título de la revista se impresiona sobre dichas imágenes (Imagen. 6).

Esta cabecera se mantiene hasta el año 1960, y con ella el discurso adoctrinador más férreo de la dictadura apoyado por diálogos como este:

Narradora: Mira esta chica con anorak. La favorece mucho ¿verdad?

Narrador: ¡Uff!, ¡qué ganas de complicar las cosas!. Este panorama de nieve me da frío.

Narradora: Verás como dentro del refugio se está mucho mejor.

Narrador: Ya veo como se quitan los guantes y la nieve, y ahora a calentarse.

Narradora: Qué bien. Todo esto debe ser la última palabra de la moda para

24 Medina, revista de la Sección Femenina, $1^{\circ}$ de julio de 1941. En Otero (2004: 133).

25 Véanse como ejemplo: Not. 368 B; Not. 370 A; Not. 394 A. 


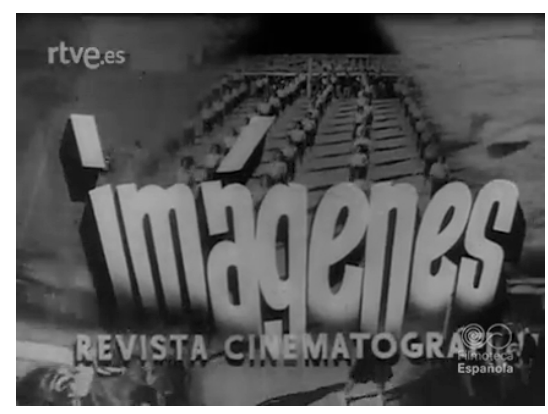

Fig. 6. Comentando la moda (Revista Imágenes. $\left.N^{\circ} 664,1957\right)$

la montaña. Conjuntos muy prácticos y elásticos que facilitan toda clase de movimientos.

Narrador: No me digas.

Narradora: Todas estas señoritas son unas grandes campeonas, y al mismo tiempo dan prueba de una gran elegancia.

Narrador: Pero, dígase lo que se quiera, les cuesta trabajo llevar los pantalones. Narradora: Es una manía que tenéis siempre los hombres.

Narrador: Si no hay más que verlas. Muy estiraditas, muy colocaditas, pero, con falda estarían mejor.

Narradora: Estos equipos son absolutamente necesarios para esquiar.

Narrador: Y también para llamar la atención. No hay más que verlas, hacen que leer, hacen que beben y en realidad todo es puro pretexto. Comentando la moda (Revista Imágenes, № 664, 1957)

\section{Recapitulando}

El estudio del Archivo Histórico NO-DO, como factor decisivo en la comprensión del documental en España durante la época franquista, obliga a incluir en su análisis aspectos económicos, políticos y sociales. Las páginas que anteceden nos llevan a concluir que tanto los noticiarios como los documentales adscritos a distintas secciones del archivo, como la Revista Imágenes, sujetos a una importante carga ideológica por cuanto suponen un medio de propaganda del Régimen franquista, muestran las marcas de un tejido cultural, político y social que hacen de ellos una herramienta más que aconsejable en las investigaciones para la recuperación de nuestra memoria colectiva.

Abordados desde una perspectiva de género, su análisis nos ha permitido comprobar cómo, a través de un elemento como la moda, y valiéndose de distintos recursos visibles, también, en otros medios de comunicación como la prensa escrita o la radio, destinados a la mujer durante el periodo autárquico, los reporteros de NO-DO desplazan la atención del espectador hacia aspectos que se encaminan a la formación y el adoctrinamiento de la población. Esta larga producción cinematográfica, admite fijar una comparativa con la historia de España en sus fases de establecimiento, desarrollo y decadencia de la dictadura franquista, que permite rastrear en estas películas los cambios surgidos en la sociedad española. Por eso resulta fácil comprender esa comunión entre lo explícito y lo simbólico que cristaliza en la construcción de unas imágenes que, acompañadas en todo momento por la voz over, se concretizan en ideas de sumisión, servilismo y abnegación de unas ciudadanas que han de convertirse en Cuerpos reproductores, Reinas del hogar, o Perfectas casadas. Estas estampas, en las que juega un papel determinante el modo de vestir y, sobre todo, la elegancia femenina, terminan impregnando el imaginario colectivo, porque participan, sin otra alternativa, en la construcción de la identidad social de la mujer en España durante el período más férreo de la dictadura franquista, de tal manera que secundan la mentira visual de un régimen patriarcal cuyos valores tradicionales, procedentes de antaño, siguen infiltrándose aún en la médula de la sociedad española. 


\section{Bibliografía}

ABELLA, Rafael (1984). La vida cotidiana en España bajo el Régimen de Franco. Barcelona: Argos Vergara.

AUMONT, Jacques y MARIE, Michele (1988). L'analyse des films. Paris: Nathan.

BENERÍA, Lourdes (1997). Mujer, economía y matriarcado durante la España franquista. Barcelona: Anagrama.

CASANOVA, Julián (2015). La dictadura que salió de la Guerra. En 40 años con Franco. Barcelona: Editorial Planeta: 53-79.

DE SOUSA CONGOSTO, Francisco (2007). Introducción a la historia de la indumentaria en Espa$\tilde{n} a$. Madrid: Istmo.

GIL GASCÓN, Fátima y GÓMEZ GARCÍA, Salvador (2010). «Al oído de las mujeres españolas. Las emisiones femeninas de Radio Nacional de España durante el primer franquismo(1937-1959)». Estudios sobre el Mensaje Periodístico, 16: 131-146.

GÓMEZ BENITO, Cristobal (2015). La mujer en la agricultura tradicional. Una mirada desde la historia y la sociología visual. En Ortega López, T (Ed.). Jornaleras, campesinas y agricultoras. La historia agraria desde una perspectiva de género. Zaragoza. Monografías de Historia Rural 11. SEHA: 210-211.

ISER, Wolfang (1987). El acto de leer. Madrid: Taurus.

JAUSS, Henry (1977). Ästhetische Erfahrung und literarische Hermeneutik, Munich, Fink. [Trad. Esp. Experiencia estética y hermenéutica literaria: Ensayos en el campo de la experiencia estética. Madrid: Taurus.

MACHADO, Cristina y FERNÁNDEZ, Juan Manuel (2015). «La mujer en el olimpismo durante la época franquista. Materiales para la historia del deporte». Suplemento especial, 2, 207219.

NASH, Mary (2015). Vencidas, represaliadas y resistentes: las mujeres bajo el orden patriarcal franquista. En: 40 años con Franco, Barcelona: Editorial Planeta: 191-229.

NIELFA, Cristobal (2003). Mujeres y hombres en la España franquista: sociedad economía, política, cultura. Madrid: Instituto de Investigaciones Feministas.

Otero, Luis (2004). La Sección Femenina. Madrid: Edaf.

PAYNE, Stanley. G (1987). El régimen de Franco, 1936-1975. Traducción de Belén Urrutia Domínguez (1. ${ }^{a}$ edición). Madrid: Alianza Editorial.

PAYNE, Stanley. G (1997). El primer franquismo. Los años de la autarquía. Madrid: Historia 16-Temas de Hoy.

PIÉROLA, Gemma (2000). Aspectos sobre el discurso moral de la Iglesia sobre la población femenina navarra en el franquismo. Gerónimo de Utariz, 16: 43-55.

PINILLA, Alfonso (2006). «La mujer en la posguerra franquista a través de la Revista Medina (19401945) » Arenal 13 (1), 153-179.

RAMOS LOZANO, Pilar (2013). Comunicación y estrategias organizativas de la Sección Femenina de Falange. Representaciones: NO-DO, 1943-1956. Málaga: Atenea.

RIQUER, Borja de (2010). La dictadura de Franco. Vol. 9 de la Historia de España, dirigida por Josep Fontana y Ramón Villares. Barcelona: Crítica/Marcial Pons.

RIVIÈRE, Margarita (1977). La moda ¿comunicación o incomunicación? Barcelona: Gustavo Gilli.

SÁNCHEZ, Rosario (1990). Mujer española, una sombra de destino en lo universal (Trayectoria histórica de la Sección Femenina de Falange (1934-1977). Murcia: Universidad de Murcia.

SORIANO, José (1942). Revista Primer Plano, $\mathrm{n}^{\circ}$ 115, 27 de diciembre: 7.

TRANCHE, Rafael y SÁNCHEZ-BIOSCA, Vicente (2006). NO-DO. El tiempo y la memoria. Madrid: Cátedra/Filmoteca Española.

TUSSEL, Javier (1999). Historia de España en el S. XX. La Dictadura de Franco. Madrid: Taurus.

\section{3}

